DE DE GRUYTER

OPEN

DOI: 10.1515/jolace-2016-0023

\title{
Mexican university teacher-researchers' biliteracy beliefs and practices
}

\author{
Jitka Crhová \& María del Rocío Domínguez \\ Universidad Autónoma de Baja California, Mexico \\ jcrhova@uabc.edu.mx \\ rocio_dominguez@uabc.edu.mx
}

\begin{abstract}
There has been a growing interest in describing higher education academic literacy. In our study, literacy is conceived as multi-layered phenomena, multiple in its character, denominated "multiliteracies" (Cope \& Kalantzis, 2013). Furthermore, within the multiliteracies frame, multilingual literacies (Martin-Jones \& Jones, 2000) are distinguished and discussed in the present paper, in particular the development of biliteracy in local academic settings. This paper explores connections between the teachers' perceptions on literacy, teachers' own biliteracy development as publishing authors and researchers. The research draws on the data obtained through a questionnaire applied in the first phase of the project to 100 participants from three public universities from northern, central and southern part of Mexico, which was completed by analysis of narratives gathered through interviews from a reduced sample of participants (31). The results seem to indicate that language teachers-researchers perceive their L2 literacy in wider terms, beyond mere reading-writing skills development and decodification of the text, which seems to be apparent in academics with higher academic credentials.

Key words: literacy, biliteracy, biliteracy beliefs and practices, language teachersresearchers' professional development

\section{Introduction}

The multiple nature of literacy — the multiplicity of its meaning — has been described and discussed from different perspectives. This multiplicity of its meaning, according to Hamilton (2012) “... [has been] historically used to justify a range of policy interventions and educational practices” (p. 1). In as much as the present day situation and our educational context, it has been acknowledged that the labor of a university teacher has diversified. Moreover, it has been documented that with the divergent nature of labor, people have turned into more multi-skilled workers, able to do complex and integrated work (Cope \& Kalantzis, 1997 as cited in New London Group, 2000).
\end{abstract}


Language teachers, in a similar way, have turned into multi-skilled experts, assuming different roles as facilitators, managers, organizers, diagnosticians, tutors, mentors, etc. in the acquisition and learning processes in diverse educational settings. Nowadays, with new information technologies, L2 teachers (as well as teachers in general) use multimodality to reach wider audiences in different forms of presenting the text (or meaning), not necessarily (or exclusively) paper-bound. Teachers also, in increasing number, engage in research activities as they disseminate knowledge, both generated and applied in their classrooms. These complex, multiple roles of a teaching profession thus require new, broadened forms of literacy. Literacy practices are also embedded socially in the communities of practice (Lave, 1991; Lave and Wenger, 1998).

Literacy studies, especially under the perspective of the New Literacy Studies (discussed further on) can also be complemented by other interdisciplinary fields, such as narrative studies (Gee, 2000). Narratives allow people to construct their own lives and make sense of their experiences (Johnson \& Golombek, 2002) within the specific social groups and cultures (the communities of practice).These narratives give account on forms of meaning-making and on the valence of disciplinary or social practices; they also enable sets of beliefs (regularly nonvisible elements) that support such literacy practices of language teachersresearchers be perceived.

In this article, we explore the beliefs that language teachers-researchers hold on literacy and document the development of their L1, L2 literacies to disclose the pattern of interdependence of teachers' educational backgrounds, beliefs and publishing activities, in the context of new demands for scholarly articles placed upon university-based language teachers. It gives an account of the mixture of beliefs and experiences that guide the decisions of university scholars to publish either in foreign language of their specialty or in the national language. Furthermore, it is shown how these decisions, once transformed into practices, are also framed by the educational policies. To fulfill demands delineated by those policies, multi-skills that language teachers possess have to be put to use in line with their beliefs on professional development.

The present study is part of a broader research project, which investigated the beliefs of foreign language teachers about research in Mexican higher education, taking as a representative sample, teachers from three public universities. In the present paper, we use the acronyms NU, CU and SU (which stand for the Northern University, the Central and the Southern University respectively). We opted for the geographical location reference instead of the real names of the institutions to protect our participants' identity. One of the axis of the longitudinal project (2012 to the date) of the Research Network in Foreign Languages, RILE by this Spanish acronym "Red de Investigación en Lenguas Extrangeras" focuses on language teacher-researchers' literacy. This longitudinal project initiated with the teachers' 
perceptions on literacy (in the first phase of the project 2012-13), continuing with the inquiry on teachers' academic literacy development through their narratives (the second phase, 2013-2014, with the selected sample of the participants from the first phase of the project), and at present (2016), the third, ongoing phase of the project), which complements the research with the data on teachers'(bi)literacy development and practices both in their academic productivity as both in the classroom and outside of it, analyzing artefacts produced by the participants from NU, CU and SU. The last phase of the project continues working with the second phase informants. This paper reports on some of the findings from the first and second phases of the project, in particular: 1. 1 the teacher-researchers' beliefs on literacy within the discipline of language teaching (phase 1); and 1.2 if these perceptions vary depending on teachers's academic credential. Furthermore, it reflects on 2.1 how language teachers developed literacy in L1 and L2 (biliteracy) as publishing authors and researchers, including their biliteracy practices and language choices for their academic production; 2.2 the above also in relation to their academic backgrounds (phase 2).

\section{Theoretical framework}

The following section provides an overview on literature revision on the concepts of literacy, multiliteracy (multiteracies), which encompass academic literacy and biliteracy. It also reflects on professional development, the role of teachers-researchers within the L2 teaching profession, their beliefs on literacy, bilingualism and biliteracy development and practices in their respective educational settings.

\section{Literacy}

Traditionally, literacy has been perceived as the capacity to decipher texts (i.e., being able to read and write texts). However knowing one's ABCs, in the conventional sense, does not necessarily imply the capacity of the effective use of the language and its comprehension in wider contexts. This broadened perspective on literacy has been adopted by the New Literacy Studies movement (Barton, 1994, 2007; Gee, 1996, Gee, 2000; Heath, 1983; Street, 1984, Street 2003; among others), which comprehends literacy as a social practice as opposed to "autonomous", skills-based approach, where literacy is broken into a set of decontextualized skills (Street, 1984; Barton, 1994, 2007), functional and rather utilitarian in the nature. Furthermore, literacy and in its' extension, is viewed as a social practice (Barton \& Hamilton, 2000; Hamilton, 2012; Gee, 1996; Street, 2003; Lankshear, 1999; Zavala, 2009), which involves everything that people do with reading and writing (Zavala, 2009, p. 25). Moreover, the extended concept of literacy nowadays includes all four skills, not only reading and writing (Cassany, 2006; Cross, 2011; Ewing, 2013). 
Literacy practices include both observable and collectable documents (texts), as well as their complements that underlie and co-construct them. In this sense, literacy practices also involve identification of the values, beliefs, and power structures that shape such practices which are more abstract than practices reported by international surveys, which focus on more common or typical literacy tasks (Barton \& Hamilton, 2000). Literacy practices (events, tasks) are embedded, situated in context of 'local' and 'translocal' (wider, or more global) communities of practice (Blommaert, 2010). Knowledge is thus embedded and distributed across the community of practice and the participants negotiate their participation in it (Gee, 2000). In our project, we follow the L2 university teachers' practices in L1 and L2 (and also beliefs that shape them) in regards to literacy (and biliteracy) development, and the valence of those practices in our participants' respective communities of practice. These practices require the effective use of languages in diverse contexts: both the traditional labor of a university teacher, i.e. knowledge creation and its dissemination in the classroom, and knowledge creation and its dissemination through publications in journals, books, etc.

\section{Multiliteracy, academic literacy and biliteracy}

In the recent years, and especially in the academic context, we can't talk about one single literacy, perceived as a set of practices of text comprehension and production, but as multiple literacies, or multiliteracies (Cope \& Kalantzis, 2013). Multiple literacies have several components and require a sociolinguistic approximation towards language and literacy, always embedded in the social practice of a given academic community, the one in which we claim a membership as language teachers-researchers. For Thorne (2013), multiliteracy entails two fundamental notions: "1) the acknowledgment of growing cultural and linguistic diversity and 2) increasing importance of digital and multimodal forms of meaning" (p. 196). Multimodal refers to the use of two or more semiotic systems (Anstey \& Bull, 2010), which, in line with the multilitercies approach, would include written, spoken, visual, and audiovisual documents (Allen \&Paesani, 2010). Both digital (technology mediated) emerging literacy practices and multimodal forms of meaning are present in all current educational settings, including higher education. In addition, in the tertiary education sector, another multiliteracy is often discussed —academic literacy.

Academic literacy is known as one of the multiple literacies (Johns, 1997), which should be pluralized as well, as it encompasses the multiple and diverse literacies found in academic contexts, such as subject and disciplinary matter courses, discourses and genres (Lea \& Street, 2006), being one of the most studied a scientific article (Swales 1990; Cassany, 2005). Academic literacy refers primarily to literacy at tertiary level (undergraduate and post graduate), although it may apply also to prior degrees (Lea \& Street, 2006). Academic literacy 
development supposes the existence of a strong link between the critical-thinking skills and the competent academic writing (Catterall \& Ireland's study, as cited in McWilliams, 2014, p.4). To determine what literacy is needed in the academic context is important to make meaning in the information-overloaded world; in that respect, Werlz et al. (2013) proved that information literacy and critical thinking are interrelated.

In our educational setting, the multiliteracies (such as academic, digital and others) combine with multilingual literacies, adding other dimension to the complexity of literacies (Martin-Jones \& Jones, 2001), overlapping slightly with adjacent fields of research- New Literacy Studies and study of bilingualism from a sociolinguistic perspective, which is also subject to critical examination of power issues (Spolsky, 1998) related to the discriminate use of languages and the preferences in the literacy curricula selection and its implementation in the given educational context (Cadeiro-Kaplan, 2004). Our present research interest on the first (L1) and the second language (L2) literacies lies on the intersections of L1 and L2 literacies, in other words, multilingual literacies. L1 and L2 literacies are not only closely linked but also transferable across languages (Cummins, 2010). According to the author, the interconnection of language systems is based on the existence of the common underlying proficiency, which makes cognitive/academic or literacy-related transfer possible (p.68).

\section{Biliteracy practices and beliefs}

Literacy in the second language is denominated as biliteracy. Biliteracy encompasses two key elements- bilingualism and biliteracy, viewed as the conjunction of both elements, previously treated as separate (Hornberger, 2003). Horberger has worked on the bilitaracy framework model since the late 80's. It fits the multilitercies model and it also retakes certain features from the Blommaert's design (2010), taking into consideration the existence of mobile multilingual repertoires in local spaces, which are simultaneously translocal and global (Hornberger, 2013). The traditional take on bilingualism and biliteracy as polar opposites, such as L1- L2, oral - written or reception - production is overcome in the development of biliteracy, one of the four-axis model of biliteracy continua, proposed by Hornberger (2013). The three resting components are the context, content and media of biliteracy. Content of the biliteracy builds on Gee's (2004) distinction between the vernacular and academic literacy also contemplated in the data analysis of the presented study.

Language practices in bilinguals include code-switching, defined as "alternation of two languages within a single discourse, sentence or constituent" Poplack (2005, p. 208), which could be considered problematic if viewed from a "monolingual mindset" (Pennycook \& Otsuji, 2015, p. 16); besides, the term monolingual, according to Canagarajah (2013) has an ideological significance and 
hardly applies to real-life situations when languages are in contact. Transfer (a cross-linguistic influence from L1 to L2, and also vice versa) is another common practice in bilinguals, already mentioned in the previous text. Transfer has been also referenced as "interference" (Jarvis \& Pavlenko, 2008), the term coined by Weinreich (1953), which has a negative connotation nowadays, as it draws attention to the negative outcomes of the transfer. Transfer may appear at all levels of the language, which also include skills or strategies, the latter documented, for example, by Perales-Escudero and Reyes-Cruz (2014) in the case of L2 to L1 transfer in one undergraduate program majoring in English in a Mexican university.

Language phenomena, language itself, as well as theories of teaching and learning or literacy practices are subject to reflection and evaluation. Teachers' thinking (cognition), the decision-making, and practices are interrelated. Literacies as social practices ways of reading, writing and using of written texts are only partially observable, as they operate on socio-cognitive level, and elements such as beliefs, values, attitudes implicated in the process are not directly observable and have to be inferred and interpreted (Hamilton, 2000). Although it has been stated on many occasions that beliefs, concepts, opinion are neighboring terms (Baker, 2011), and have been treated in literature as synonyms (Pajares, 1992). For our research purposes, we selected a set of definitions of beliefs, provided by Pajares, as suitable for our current research framework: individuals develop a belief system that houses all the beliefs acquired through the process of cultural transmission; this belief system helps an individual define and understand the world, and knowledge and beliefs are closely connected and that beliefs constitute a filter through which phenomena are interpreted (p. 325). Borg (2003, as cited in Borg, 2006), uses the term language teacher cognition as encompassing beliefs, knowledge, theories, attitudes, images, assumptions, metaphors, conceptions, and perspectives (p.41). Similarly to Borg (2006), we agree that there is a connection between beliefs, practices and teachers' knowledge. Cognition, acknowledgement of the processes of learning-to-teach and what constitutes the knowledge in the discipline is linked to professional development.

\section{Professional development: Teachers as researches}

Professional development is closely related to literacy development. The most salient characteristic of occupations that are "traditionally thought as professions is that they require advanced education and extensive training" (Nunan as cited in Bailey, Curtis, \& Nunan, 2001, p.13). According to Nunan, the existence of advanced education and training is the first one listed of the four basic criteria that determine whether or not language teaching can be legitimately considered a profession. The professional development of the Mexican language teachers was influenced by the availability of teacher formation programs. It was not before the 
90s when BA programs in language teaching spread (Da Silva y Gilbón, 1995; Sayer, 2007). Progressively later (in the 2000s), MA programs follow (Ramírez Romero 2010), yet still with virtually no coverage in doctorate programs in the specific area of foreign language teaching (Ramírez-Romero, 2013) at national level. Limited availability of the educational programs resulted in the lack of trained professionals, which caused a delay in professional trajectories of Mexican language teachers, and enable that language teachers were "launched" (Lengeling, 2007,2013 ) into the profession from diverse educational backgrounds. It is also common that the education backgrounds of the university teachers in the discipline are partly in Mexican and partly in foreign institutions, which enhances biliteracy. The initial employment criteria for a language teacher in past was, in many cases, the fluency in the target language. Language teachers then worked mostly in language centers affiliated to universities.

Teacher formation and training typically happened simultaneously with their job as full-time professors until the 90s, when the national and institutional policies changed, which emphasized their participation in research, administration and community services. Furthermore, there was a demand to reach the desirable academic standard for university professors, including the language center staff; this situation led teachers to enroll in undergraduate and graduate studies, which also encouraged research and was expected to eventually increase the academic productivity. Allocation of funding and benefits, in line with the politics of evaluation, made university teachers work collaboratively in formal research groups (CA, by its Spanish acronym), affiliate to Professors' Improvement now Professors' Development Program (PROMEP, since 2013 renamed to PRODEP; referenced by its current Spanish acronym hereafter), to the National System of Researchers, (SNI, initials in Spanish) and compete for individual university productivity bonuses. All the above initiatives support faculty to conduct research as well as they promote productivity, which springs from literacy and at the same time enhances it.

Literacy is also research-based and research-driven. The institutional requirements and practices in university teachers in Mexico and elsewhere demand from academics increasing presence as publishing authors. Research in language teaching field in Mexico has been scarce (Ramírez-Romero 2007, 2010, 2013) as well as the resulting productivity. Moreover, language teachersresearchers did not have the opportunity to acquire the research skills at the early age; they learn how to research at the same time as they perform the activity (Reyes-Cruz \& Hernández-Méndez, 2014).

Research on literacy has developed mainly in the Anglophone context, although the situation gradually changes. Before 2002, articles on academic literacy written in Spanish were almost inexistent, while in last decade their number has grown (Carlino, 2013). Academic literacy and the research on L2 writing in Mexican 
universities is concentrated mainly in the books edited by Perales-Escudero (2010) and Santos (2010), both written in English. Regarding the language choice for academia, English is a lingua franca of the scientific communication (Mauranen, 2006). Prestige and visibility in the academia (Tardy, 2004) can be thus reached through publications in English, "lingua franca of research and scholarship" (Hyland, 2009, p. 4), converting English into an additional academic skill more than a language itself, according to the same author. The possibility to be cited also increments when publishing in English. Researchers in the periphery (non-native speakers) might feel underrepresented the current scenario as they might not know the genre specifics and contrastive rhetoric or simply the English language to get published (Englander, 2010). On that respect, Hyland (2016) targets beliefs on editors and referees bias towards non-Anglophone writers, claiming there is no research evidence that would prove such a claim. Moreover, in the applied linguistics and language teaching, non-Anglophone publications outnumber Anglophone researchers. As knowledge is constructed through publications, it is important to foresee where our participants are headed and if in the near future we are not going to face a diglossic situation where languages other than English would not be used for academic purposes.

Given the above, we stated our research questions as follows: 1. 1. What are the teacher-researchers' beliefs on literacy in the Mexican higher education context? 1.2. Do their perceptions vary according to their academic credentials? 2.1. How have language teachers developed literacy in L1 and L2 (biliteracy) as publishing authors and researchers, including their biliteracy practices and language choices for their academic production? 2.2. Do their practices differ in relation to their academic backgrounds?

\section{Methodology}

\section{Phase 1}

The present study is part of a broader research project which investigated the beliefs of foreign language researcher-professor about research in Mexican Higher education. The project was carried out in two phases. The first phase of the study had the intention to identify the beliefs of 100 researcher-professors regarding research self-efficacy, collaborative research, research and thesis supervision and literacy. A 96 likert-scale questionnaire was designed to gather data. To estimate the reliability of the instrument the Cronbach's Alpha test was run, obtaining a reliability coefficient of .855 . Given the scope of the study, we report exclusively on the literacy items (see Annexes) in this paper.

\section{Phase 2}

This part of the project uses qualitative methodology. The data was analyzed through the procedures of content analysis (Mayring, 2000). To elicit the responses, semi-structured interviews were carried out, based on the set of eleven 
leading questions that enabled us to obtain large chunks of information from the studied subjects. The categorization of the main themes and subthemes were established based on individual categorization of three researchers and only the categories where the consensus among the researchers was reached remained in the study. As a result, patterns and pathways of academic literacy development in language teachers could be established, where the following central teams arose: 1. university teachers-researchers developed their literacy through their prior schooling and participation in academic/teacher training courses; 2 . literacy is also enhanced by academic productivity; 3. engagement in research projects; 4 . through the development of specific academic skills related to reading, and finally, given the specificity of the sample, 5 . biliteracy and bilingualism development theme, which emerged in the analysis of the data obtained through language teachers' narratives. Given the delineated objectives and limited space the present paper relates exclusively to themes 1 and 5 .

\section{Context}

The study was conducted in three large Mexican public universities, located in three distinct, geographically representative areas (north, center and south). These institutions prepare future foreign language teachers in accredited BA and MA programs, recognized for their quality by the National Council of Science and Technology (Conacyt, by its Spanish acronym). CU offers Bachelors both in English and French Language Teaching in bilingual programs. CU was one of the first to implement BA in Foreign Language Teaching in Mexico in the 80s; NU and CU's BA programs initiated in the 90s. NU currently offers Bachelors in Language Teaching, with curriculum in English-Spanish content-based classes with a third language taught as a subject. Besides BA in Language Teaching, NU also provides BA in Translation. SU educational offer includes BA in English Language, with French or Translation as specialties. MA programs in all three universities date back to the first decade of the 2000s. NU offers an MA in Modern Languages, CU an MA in English Language Teaching and SU an MA in Education that contains a specialty in Didactics of English. NU and SU are located in the border area with English speaking countries (U.S. and Belize). All teachers that participated in both phases of our study are involved in the previously mentioned educational programs.

\section{Participants}

Phase 1

This part of the study involved 100 professors from three different language schools in public universities. They were professors who were working at these institutions ( $N U, n=33, C U=32, S U=35$ ), either as part time or full time teachers. They all had experience doing research in the field of language learning and teaching, and had published at least one of these academic products: dissertations, 
articles, books or chapters of books. Most of them held a Master degree $(n=70)$ and some also held a Ph.D. degree $(n=20)$. Some of them were members of the SNI, National Researchers System $(n=14)$ or had obtained the recognition of the Professional Teacher Development Program from the Ministry of Education, PRODEP $(n=53)$ and were working in a registered research group (CA) with different level of consolidation. Table 1 contains a summary of the demographic data of the participants.

\section{Phase 2}

In this part of the project, the original sample of 100 participants was reduced to one third. The second phase participants were selected on the base of their productivity, academic degree, type of contact (only the full-time teachers, research professors, members or collaborators of CA, SNI or PRODEP membership holders, actively involved in the research and publishing authors were included). The plan was to interview 10 participants from each university, but given to circumstances and participant availability, NU researchers, who were in charge of the instrument recollection in the rest of the country, could gather the narratives of 10 participants from the NU (participating researchers were excluded from this sample), 9 from the CU and 12 from the SU, in total 31participants, who were interviewed in 2013-2014 period.

Table 1. Demographic data of the participants (2012-2013)

\begin{tabular}{|c|c|c|c|c|}
\hline $\begin{array}{c}\text { Years } \\
\text { teaching a } \\
\text { foreign } \\
\text { language }\end{array}$ & $\begin{array}{c}\text { Years } \\
\text { researching }\end{array}$ & $\begin{array}{c}\text { Academic } \\
\text { degree }\end{array}$ & Contract type & $\begin{array}{c}\text { Academic } \\
\text { Recognition }\end{array}$ \\
\hline $1-10=22 \%$ & $1-4=54 \%$ & $\begin{array}{c}\text { Diploma } \\
1 \%\end{array}$ & Full-time $=72 \%$ & PRODEP $=45 \%$ \\
\hline $\begin{array}{c}11-20= \\
62 \%\end{array}$ & $5-10=33 \%$ & B.A. $=8 \%$ & Part-time $=4 \%$ & $\begin{array}{c}\text { SNI Candidate } \\
11 \%\end{array}$ \\
\hline $\begin{array}{c}21-30= \\
16 \%\end{array}$ & $11-30=13 \%$ & M.A. $=70 \%$ & $\begin{array}{c}\text { Hourly lecturers } \\
20 \%\end{array}$ & SNI $=3 \%$ \\
\hline & & PH.D. $=20 \%$ & By contract $=4 \%$ & None $=41 \%$ \\
\hline
\end{tabular}

\section{Instruments}

Phase 1

To research language research-professors' perceptions of literacy, a 12 item Likert-scale survey was designed. The items addressed two main topics: language for literacies which refers to the use of language to develop literacies, and literacy for professional development, which explores specifically the relationship between literacy and professional development. Item writing was guided by Cross's work (2011); some of them were adapted from the questionnaire this 
author designed to explore the understanding of literacy of teachers of English as an L2 in Australia. The 12 items had six response options: I strongly agree, I agree, I cannot decide, I disagree, I strongly disagree, and I do not know, the values ranged from 1 to 6 . In the current study, participants were asked to respond to each item based on their perception. The instrument is in appendix 1.

\section{Phase 2}

In the three university locations, a set of 31 semi-structured interviews, based on the script of 11 leading questions, had been conducted in order to ascertain the information required to obtain data (responses on the research questions). The interviewers were the postgraduate students of the MA program from the NU mostly, with the participation of the researchers who also directly participated in the field work. The corpus contained in total 9 hours 53 minutes auditory data obtained through semi-structured interviews, transcribed and analyzed.

\section{Data analysis}

Phase 1

Data gathered from the questionnaire was analyzed via SPSS 19 by calculating mean and percentages of the answers and present results. In order to establish if there were statistically different responses of the two groups of teachers with doctorates or masters, Mann-Whitney U test was carried out.

\section{Phase 2}

The data of the teachers were obtained through semi-structured interviews; the analysis was done through the procedures of the content analysis. The classification and the identification of main themes and subthemes (topics and subtopics) were done manually, by three codes independently. The final selection of the categories was based on consensus of the participating researchers. The patterns and pathways of academic literacy development in language teachers were established in this process, where the following central teams arose. 1. University teachers-researchers developed their literacy through their prior schooling and participation in academic/teacher training courses. 2. Literacy is also enhanced by academic productivity, and 3. engagement in research projects. Literacy requires 4 . the development of specific academic skills related to reading and writing, and finally, based on the specificity of the studied population, 5 . biliteracy and bilingualism development as the final major theme, which emerged in the analysis of the data obtained through language teachers' narratives. Given the delineated objectives and limited space, the research topics (themes and subthemes) which are reported and analyzed in this paper relate exclusively to themes 1 and 5 (research question \#2 in the present paper). 


\section{Results and discussion}

\section{Phase 1}

The research aimed to find answers to the following questions (RQ 1.1): What are the teacher-researchers' beliefs on literacy within their respective discipline in the Mexican higher education context?

RQ 1. It was found that most university teachers agreed with the items related to the following topics identified in the beliefs on literacy questionnaire: 1 . Language for literacy and 2. Literacy for professional development as it is observed in the next part of this report.

Language for literacy.

The participants of the study expressed agreement with the idea that literacy implies the development of the four main language skills (Cassany, 2006, Ewing, 2013) and that it does not refer only to reading and writing. $90 \%$ of the professors agreed with item 1: Literacy development in ESL involves a focus on all four macroskills ( $\mathrm{M}=1.7), 55 \%$ strongly agreed and $35 \%$ agreed.

Item 2. Literacy development in L1 facilitates development of literacy in L2 or L3 $(M=1.57)$ obtained the highest percentage of agreement $(96 \%)$ in the results. It seems they coincide with Roberts (1994) who concludes that there is enough research evidence that basic literacy skills developed in L1 transfer to L2, but that it depends on the definition of literacy we stand for. Additionally, psycholinguists, Steinberg, Nagata and Aline (2000) also state that cognitive strategies in L1 are usually transferred to the L2 and the L3. It also seems to prove Cummins' (2010) point on the existence of the common underlying proficiency.

Literacy implies the use of multimodal texts which are defined as those that integrate two or more semiotic systems (linguistic, visual, audio, gestural or spatial); and they can be delivered through different media or technology (Anstey $\&$ Bull, 2010). Some examples are a magazine, a web page, or a television program. Professors showed agreement in item 3. Literacy development implies the use of multimodal texts (visual communication means) $(\mathrm{M}=1.9), 37 \%$ strongly agreed and $50 \%$ agreed.

On the other hand, literacy also involves the development of digital skills by using information and communication technologies (digital literacy, c.f. Thorne, 2010), as stated in item 4. Literacy development involves the effective use of information and communications technologies $(\mathrm{M}=2.2)$. In this statement professors' answers were different since $75 \%$ agreed, $12 \%$ could not make a decision, $10 \%$ disagreed, and $2 \%$ said they did not know. This variation in the answers might indicate a possible generation gap between professors and students (Snyder, 2003) and that some professors do not relate the use of technology with literacy. This confusion could be due to the fact that technology 
has been related to literacy is different ways: as a deliverer of literacy, as a place for interaction around texts and as a medium for meaning-making (Burnett, 2010).

In item 5. Literacy development is highly related to the development of critical thinking ( $\mathrm{M}=1.9$ ), we found that $86 \%$ agreed ( $40 \%$ strongly agreed), $8 \%$ could not decide and $4 \%$ did not know. This results show that professors relate critical thinking with literacy development. Critical thinking has recently been related with information literacy since it has been considered a key issue to negotiate the information overload (Wertz et al., 2013).

Item 6. My level of literacy is the same in Spanish and in the language I teach has the intention to identify how biliterate professors think they are. The mean was 2.6 which shows a tendency towards indecisiveness and disagreement, 60\% agreed (only 18\% strongly agreed), 13\% I could not decide, and 24\% disagreed. It seems professors do not feel comfortable with their L2 literacy.

As a summary of this part of the results, we conclude that most of the professors believe that literacy development involves all four macro skills, the use of multimodal texts (visual communication means) and the development of critical thinking. They also believe that L1 literacy skills are transferred to the development of L2 or L3 literacy. However, there were some discrepancies in their answers about these two ideas: Literacy development involves the effective use of information and communications technology (ICT) and that their level of literacy is the same in the official language (Spanish) and in the language they teach.

In reference to the topic "Literacy for professional development", results showed that most professors agreed with the statements $(M=2.0-2.5)$ with some discrepancies, though. The highest percentage of agreement was for item 9. Active participation in research encourages literacy development (82\%) and the lowest was for item 11. My level of literacy is evident in my academic production (publications, paper in proceedings, etc.) (64\%). This item also presented $17 \%$ of disagreement, $12 \%$ could not decide and $7 \%$ did not know. The second highest percentage of agreement was in item 7. Literacy development implies to communicate effectively in collaborative activities, $81 \%$ agreed, but $12 \%$ could not decide and 3\% did not know, and only $4 \%$ disagreed.

Item 8. Active participation in the professional community encourages literacy development (69\% agreement, 19\% undecided, $5 \%$ disagreement and $7 \%$ I do not know) presented the highest percentage of I cannot decide answers, what might show that those professors do not participate actively in the professional community possibly because they are hourly lecturers (20\%) and are not sure to what extent literacy development might encourage active participation in that particular professional community.

In item 10. The level of literacy of a professor determines the level of research, 65 $\%$ agreed, $12 \%$ could not decide, $16 \%$ disagreed and $7 \%$ did not know. This item presented the second highest degree of disagreement. Finally, in item 12. Literacy 
development is closely related to professional development, 67\% of professors agreed, $16 \%$ could not decide, $12 \%$ disagreed and $4 \%$ did not know.

In general terms, this statistical analysis showed that it seems professors relate literacy development to different issues linked to professional development such as academic production, active participation in professional and research activities and professional development itself. It was observed that, even though disagreement was not frequent in the answers, it was higher in the set of items denominated as "literacy for professional development" than in the previous set related to "language for literacy. Indecision and lack of knowledge percentages, and some disagreement with these ideas might be interpreted as a possible lack of previous reflection on these issues. However, their answers might also be closely related to these professors' context. Full-time professors are encouraged to work collaboratively, $53 \%$ are associated to a CA membership in the three universities as result of a national policy supported by the Ministry of Public Education. This situation has given university professors the opportunity to improve their academic production associated to the development of research projects, which has implied the development of academic literacy practices such as papers, books and thesis writing.

To respond the RQ 2.2., and determine if there were any differences in the responses of the teachers with doctorates comparted to those with and with the masters, the Mann-Whitney U test was conducted, which revealed statistical differences in four items from the questionnaire: \#1 (sig. 0.016), \# 9 (sig. 0.037), $\# 11$ (0.004) and \#12 (0.009). In all cases, teachers with doctorates endorse more than teachers with masters the following statements: Literacy development in ESL involves a focus on all four macroskills, The level of literacy of a professor determines the level of his/her research, My level of literacy is reflected in my academic production and lastly Literacy development is closely related to professional development. The previous results may indicate that teachers with higher academic credentials perceive literacy in wider terms, with all four skills included, not just reading and writing. This result seems to support previous results obtained in a preliminary study (Crhová, Domínguez-Gaona, Molina-Landeros, Arias-López, \&Thomas-Ruzic, 2014), which reflected a similar finding based on a reduced sample of participants (just one of the participating universities), in which $100 \%$ of doctors totally agreed with the proposition, while only $82.1 \%$ agreed with the statement. In addition, we observed certain interdependence between the research experience and the confidence, and academic habilitation since the participants with doctorate identify more with the idea that their level of literacy determines their level of research. Similar results were observed by Reyes-Cruz \& Gutiérrez-Arce (2015), when studying research efficacy beliefs in students of an MA program related to the context of our current research. The study documents that the students upon concluding the MA degree report only a moderate research 
self-efficacy; the changes in research self-efficacy from moderate to high are expected in the doctoral studies, which is in line with the our research findings. In as much as academic productivity, it has been documented that it is higher in number in academics with higher credentials (Ramírez-Romero, 2013), which at the same time matches the realistic perceptions that the teachers-researches have of their own productivity as reflected in this study.

\section{Phase 2}

This phase of the research project holds as purpose describing the development of literacy of teachers-researchers in the field of language teaching in three Mexican universities through the interviews, focusing namely on how language teachers developed literacy in L1 and L2 (biliteracy).

RQ 2.1: How have language teachers-researchers developed literacy in L1 and L2 (biliteracy) and which languages they use in their academic production; the above also in relation to their academic backgrounds (RQ2.2).

In this section, the results of the information that was gathered is exposed and interpreted. Firstly, we evidence the literacy development of our participants through their participation in academic programs and courses (table 3) and next, we document (table 4) biliteracy (and bilingualism) development in their academic production, providing excerpts from teachers' narratives.

From the previously mentioned, it results evident that educational backgrounds marked academic literacy of our participants. In the interview, they described their academic degrees and the field of specialization as antecedents for their literacy development. They also mentioned their participation in academic and teacher training courses. In reference to the development of literacy (L1 and L2) and as a response to RQ 2, 30 out of 31 participants mentioned in their narratives their previous bachelor's degrees as a relevant factor. 23 of them specified that their BA educational background was in the field of applied linguistics and similar degrees. Two participants' degrees were related to education in general, four participants' degrees are not related either to applied linguistics or education in general, and finally, one participant did not specify the BA degree obtained in the course of the interview. The most frequent responses regarding the BA antecedents belong to the Sub-category ' $A$ ' (Applied linguistics and related); the following excerpt exemplifies it.

I have unfinished didactics studies at UAG and I have a Bachelor's Degree in Educational Philosophy, but-with-it, it — held an emphasis on English Teaching uhm...from St. Mark and St. John's College in Exeter University in England.(1NDF). ${ }^{1}$

${ }^{1}$ Participants are identified by a code. The initial letter refers to participant's number, the first letter refers to the university ( $\mathrm{N}=$ Northern, $\mathrm{C}=$ Central, $\mathrm{S}=$ Southern University); the 
Table 3: Literacy Development through the Participation in Academic Programs and Courses

\begin{tabular}{|l|l|l|}
\hline Main category (theme) & Subcategory (subtheme) & Frequency (n=31) \\
\hline $\begin{array}{l}\text { Through their } \\
\text { participation in academic } \\
\text { programs }\end{array}$ & $\begin{array}{l}\text { I) Bachelor's: } \\
\text { A. Applied linguistics and related } \\
\text { B. Education and related } \\
\text { C. Non-related field } \\
\text { D. Non-specified field. }\end{array}$ & A) 23 \\
& B) 2 \\
& C) 4 \\
& $\begin{array}{l}\text { II) Master's } 1 \\
\text { Applied linguistics and related } \\
\text { Education and related } \\
\text { Non-related field }\end{array}$ & B) 14 \\
& Non-specified field & C) 0 \\
& D) 5 \\
\hline & $\begin{array}{l}\text { III) Doctorate: } \\
\text { A. Applied linguistics and related } \\
\text { B. Education and related }\end{array}$ & B) 5 \\
& C. Non-related field & C) 0 \\
D. Non-specified field & D) 2 \\
& & \\
\hline & $\begin{array}{l}\text { IV) Participation in } \\
\text { academic/teacher training } \\
\text { courses }\end{array}$ & IV) 16 \\
\hline
\end{tabular}

On the other hand, there are some teachers-researchers in our field, whose BA degrees do not directly relate to the discipline they currently teach, such as documented in the following testimony:

Well, what happened is that I ended up as an English teacher uhm...in a peculiar way, because I have a Bachelor's Degree in Biology. So, uh....due to a twist of fate, I didn't practice as... I didn't practice as a biologist. And I learned English since I was very little, so, uhm....there was a, here in the university, there was a call for English teachers and they said: you can, you can do it. (17CMF).

Contrastingly, in the postgraduate studies, when continuing with their master's degrees, we do not find participants who explicitly state that their masters are in fields unrelated to their current teaching positions. The masters they hold are either in the field Applied linguistics and related (mentioned by eleven

second letter refers to the degree (M for Master's and D for Doctorate), the following letter represents the gender ( $\mathrm{F}$ for Feminine and $\mathrm{M}$ for Masculine); $\mathrm{S}$ stand for currently studying doctorate at the end of the code descriptor. 
participants) or Education and related (frequented by six participants); however, there were five informants, who did not specify their master's degrees in the interview, such as documented in the following excerpt:

[...] and it was some years after I had finished the BA, like seven years after the $B A$, when I started the masters courses in a French University of Clermont-Ferrand in France, and well, until there, no? And probably soon, I'll start the doctorate, but not at this moment. (10 NMM).

The doctoral degree is a referent of academic literacy, explicitly mentioned by thirteen participants, who hold the degree either in Applied Linguistics and related fields (A) $(n=6)$ or in Education and related (B) $(n=5)$. In addition, two participants did not specify their doctoral degree during the interview, although considering their educational background is known to the authors of this text, these two participants would be listed in the A sub-category. The most frequent responses for the both A and B sub-categories of doctoral studies could be documented in the following two excerpts:

And... lastly, the Doctorate in Linguistics in the Autonomous University of Queretaro. (3NDM).

[...] and lastly, the Doctorate in Education in the University of Guadalajara, Marista of Guadalajara. And well, here I am since 1993, teaching, well then, almost for 28 years, right? (15CDM).

It should be mentioned that those who obtained their degree in (A) type of programs in Mexico where usually recently obtained degrees, while the (B) type of doctoral degrees include titles achieved previously, in programs established in the national territory; nevertheless, the vast majority of the $\mathrm{PhD}$ of the (A) type in our field were obtained in foreign universities as could be evidenced from a following excerpts.

$[P h D] . .$. in Applied Linguistics. This time at Macquarie. The same as [mentions other colleague who studied the same program]. And then they came, they gave us courses for several weeks and left, and we continued being autonomous, finishing the tasks. (14CDM).

... and a doctorate in English and Education from the University of Michigan. (21SDM).

In addition, a significant number of participants acknowledged that participation in academic courses and teacher training programs shaped their academic literacy within the discipline. 16 out of 31 informants mentioned they engaged in those kinds of courses either as attendees or, at occasions, as instructors. In both cases, their involvement in those courses marked the development of their literacy within their respective discipline. The following two excerpts document the experience of the attendees to those courses. 
And then I did some studies in training, for teacher's training of English teachers in Edinburgh, in Heriot-Watt University... (1NDF)

The second, more detailed testimony was provided by one of our participants.

..I have a COTE, the Certificate for all- how was it? For Teachers, Overseas Teachers of English, the COTE, the one from Cambridge....Cambridge? Yes, it is from Cambridge, correct me if I am wrong, right... (2NMS)

In overall, the results obtained in the data analysis show consistency and similarity in intercampus comparison. The significant number of participants reported that their academic degrees, linked directly to the development of their literacy level, especially at postgraduate level, were obtained in a foreign university (mainly in Anglophone countries). The previous can be understood considering the limited coverage of the programs in the area of foreign language teaching at national level. According to Da Silva y Gilbón (1995), BA offer until the late $80 \mathrm{~s}$ and $90 \mathrm{~s}$ was restricted to just few universities, and it was not until the early 2000s when the coverage of these programs amplified significantly, offering also some limited options for those interested to enroll to MA programs (Ramírez Romero, 2010), yet still with virtually no coverage in doctorate programs (Ramírez Romero, 2013) at national level. Therefore, it does not result surprising that our participants' academic formation at masters and doctorate levels happened abroad (such as documented above by our informants 1NFD, 10NMM, 14CDM, and 21SDM, among others), or that the professionalization within the discipline was delayed as a result of the teachers' entering into the discipline with diverse educational backgrounds, combined with empirical foreign languages knowledge, which was back then a sufficient qualification for a foreign language teacher (e.g. 17CMF). In that respect, Sayer (2007) remarks that the BA programs in English teaching were created to professionalize the teaching practice in English language teaching in Mexico in the 90s.

The relative shortage of academic offer in the discipline at the time many of our participants studied their BA degrees also explains why we find teachers with BA degrees not related to the field they currently teach, and why, teacher training courses were vital components for teacher formation within the discipline. Among the courses that had high impact on English teachers' professional development from the mid-90s to the early 2000s in Mexico, COTE should be mentioned in the first place (such as reflected in the narrative of 2NMS). This one-year EFL (English as a Foreign Language) in-service training course offered by the University of Cambridge through the British Council, officially recognized by the Mexican Ministry of Education (SEP) in 2000 (Lengeling, 2007), provided graduates of those courses with credentials required for professional entry into EFL discipline, where many of the teachers "fell" (Lengeling, 2007; Lengeling, 2013) from diverse educational backgrounds. COTE-trained teachers then participate in BA programs 
(Sayer, 2007); having both COTE (and other) courses and the BA in English Language Teaching (ELT) openings the biggest impact on ELT in Mexico, according to Davies (as cited in Wilson, 2015). In the same text, Davies also acknowledges that the ELT profession in Mexico is turning more academic at present, with the increasing presence of masters and doctorates in Applied Linguistics and ELT; however, in his opinion, the BAs in language teaching are sole beneficiaries of this academic literacy and professionalization increase, meanwhile the ELT practices in other undergraduate programs (BAs) or prior educational levels remain unchanged.

The second research question addressed in the project, the development of academic literacy in language teachers-researchers, brought up specific themes relative to biliteracy and bilingualism development and also practices in researches as publishing authors and their language choices. The following table concentrates the results, which will be analyzed further on in the text.

Table 4: Bilingualism and Biliteracy Development

\begin{tabular}{|c|c|c|}
\hline $\begin{array}{l}\text { Main category } \\
\text { (theme) }\end{array}$ & Subcategory (subtheme) & $\begin{array}{l}\text { Frequency } \\
(n=31)\end{array}$ \\
\hline $\begin{array}{l}\text { Bilingualim } \\
\text { and biliteracy } \\
\text { development }\end{array}$ & $\begin{array}{l}\text { I. Bilingualism and biliteracy through } \\
\text { A) Academic literacy practices } \\
\text { - early bilingualism, L2 in L1 classroom } \\
\text { settings } \\
\text { B) Vernacular literacy practices } \\
\text { - a) L2 language at home, early } \\
\text { bilingualism } \\
\text { - b) natural settings, late bilingualism } \\
\text { II. Code-switching*** } \\
\text { A) Self-reported } \\
\text { B) Perceived }\end{array}$ & $\begin{array}{l}\text { I. } \\
\text { A) } 3 \\
\text { B) } 4 \\
\text { Ba) } 3 \\
\text { Bb) } 1 \\
\text { II. } \\
\text { A) } 4 \\
\text { B) } 11\end{array}$ \\
\hline & $\begin{array}{l}\text { III. Biliteracy in academic production } \\
\text { A) Spanish (L1) } \\
\text { B) Spanish (L2) } \\
\text { C) English (L1) } \\
\text { D) English (L2) } \\
\text { E) Spanish and English } \\
\text { F) Spanish and French } \\
\text { G) Varieties of Spanish }\end{array}$ & $\begin{array}{l}\text { III. } \\
\text { A) } 11 \\
\text { B) } 1 \\
\text { C) } 2 \\
\text { D) } 4 \\
\text { E) } 11 \\
\text { F) } 2 \\
\text { G) } 1\end{array}$ \\
\hline
\end{tabular}


The incial interest was to describe teachers' biliteracy development as publishing autors. However all the transcripts in the procedures of content analysis disclose more themes and subthemes in the narratives of our participants. Some participants $(n=10)$ made specific refernce of the way they became bilingual (and biliterate). It can be inferred from the respones of our participans (not contained in the above table) that the majority aquired their L2 later in life, in academic contexts, thhrough academic literacy practices, as Gee (2004) labels them. Both NU and SU geographical location in the border area with English speaking countries (U.S. and Belize) might have facilitated in some of participants the development of vernacular literacy in L2. One of the NU participant's close relatives spoke only English, so it became one of the languages used at home, in her own words:

[Before starting university] I did not have any professional education, I only had high school and I was bilingual because my grandpa, well ....was American and this is the reason why I could speak English. (5NDF).

Other SU participant was raised and received her schooling prior to university in an English-medium in Belize with her Mexican parents. We can infer from her responses that English was the dominant literacy and Spanish was her vernacular language, as she characterizes herself as a native speaker of English, the only one from her sibling that remained biliterate (and bilingual):

...knowing English and being a native speaker, I was given the opportunity to get a job in the area of English....but from my brothers, I am the only one that remained with both languages because I used to read, and read in English, and read in Spanish. [...] I am not from Mexico, but my parents are Mexican... (28SMF).

Three of our 31 participants are native speakers of English, but all are proficient in Spanish (language of the interview). One of them acquired Spanish in vernacular settings (community) as late bilingualism. In his narrative, he says he would like to possess the academic literacy in Spanish:

I read academic texts, I think that with some help, I could produce an academic text in Spanish for publication. [...] it would give a great deal of satisfaction to say, look, I could do it in Spanish as well, the same way you can do it in English. I feel impressed that my colleagues can master, their...their foreign language that well; so impressive that they publish in English, I wish I could say the same. (14CDM)

Only few participants $(n=3)$ report code-switching, the existence of the language transfer or interference as conflicting phenomena that influenced at some point their academic literacy. One teacher reports problems related to language transfer upon entering to MA program in Mexico after studying her BA in the U.S; transfer from her L2 into her L1: 
We were the first generation of the MA and so they were considerate with us, basically because of a lot

of interferences from the English language, honestly. So, they help us to realize these were anglicisms sometimes, and sometimes they were the structures... ( 5NDF)

Other participant from the same institutions had similar problems, without studying abroad, but studying a BA in English caused her problems when she started her MA, with transfer from L2 (English) to L1(Spanish).

During the interview, our participant also committed occasional codeswitching, a practice common to bilinguals. Interestingly, the four teachers of French from sample did not code-switch from Spanish to French. The switches we observed were mainly lexical; usually one word switches or a single phrase switches in 11 out of 31 participants. The switched English elements referred frequently to language skills, foreign methodology terms, and specific features of writing or publishing. Code-switching in this context serves a marker of solidarity in bilinguals (Garret, 2010); moreover, transfer is related to identity changes or selection of new identities, as a result of biliteracy; the latter documented in Mexican university teachers' L2 writing (Crawford et. al., 2014).

The publication preferences of our participants were the following 12 out of 31 publish exclusively or almost exclusively in Spanish, 6 publish in English, or almost always in English, 11 report that their productivity is both in English and in Spanish and two publish in both French and Spanish. In this context, one participant mentioned that she had to master another variety of Spanish (peninsular Spanish) in her academic literacy practices, as she was studying her doctorate in Spain.

The teachers also expressed literacy practices, preferences in language selection and beliefs associated, or mentioned the recent shifts in mind. Some of the reasons for publishing in English are documented in the excerpts.

My discursive community generally demands this kind of publication from me [i.e. written in English]. This is probably the reason I have gotten more into English. There are more publications and places to publish in English. (18CDM).

A participant publishing in both languages wants to retake English again, as

[...] publishing in English has--- opens doors to much wider audiences (1NDF).

Other three academics, display an orientation towards publication in English, although they have published in Spanish so far:

of course, if the publication is in English or other language, it is a plus for you, don't you agree? (2NMFS).

I explore the possibilities to publish in English, but in reality I haven't done it... not so far. (3NDM). 
Lately, I've been working on linguistic transfer. My goal is to get published in English [...] as it has more impact that means more people read you. (3NMFS).

On the other hand, some of the teachers who have been publishing in English also shift their practices and include progressively more Spanish, as seen in the following example.

But I also see the convenience in publishing in Spanish to reach other audiences. (11CDF).

Our participants feel, in general confident, in publishing in both languages (English-Spanish), in cases of teacher of French, only one participant considers that publishing in French journals is out of his reach and other participant considers more convenient to publish articles in English, in collaboration with her peers, who would provide some editing in English. Interestingly, one participant, whose L1 is English, publishes more in her L2 (Spanish), as a matter of convenience, since the institutional research reports are required in Spanish. What was also rather unexpected was the expressed unwillingness to publish in the mother tongue (Spanish) in two of our participants disclosed during the interview.

\section{Conclusions}

The general tendency, as perceived form the narratives, is to reach a balance in publications, at least as much as English-Spanish representation. This is particularly visible in the participants from NU, where the Spanish-only prevails in the academic production; however, as we explored our participants' beliefs and plans for future publications, this situation was changing -they were already working on their first articles in English or firmly decided on publishing in English. They have realized that publications in English have more impact and hence enable them reach major visibility and prestige, in line with Tardy (2004) or Mauranen (2006). On the other hand, some of our participants publishing in English recently include also publications in Spanish. There is no indication that the academic writing in the area of language teaching would be headed towards English exclusive domains, at least not in the near future. English, though, will remain, by far, ahead of French in foreign language publications for Mexican teachers-researchers from our sample, which reflects the matriculation in the L2 programs majoring in French language teaching (in $\mathrm{CU}$ ) or the minor representation of French in the BA in Language teaching and MA in Modern Languages (NU), or in the case of SU, its presence as a curricular subject in diverse bachelors.

In response to second research question, we can't generalize on such a small sample, nevertheless, as an indicator, we observe that among of those who publish only in English (or almost exclusively in English) $5(n=6)$ have doctoral degrees (83.33\%). The MA degree holder, who publishes in English, is a native speaker, 
which means that all the non-Anglophone teachers-researchers publishing in English have doctorates. By contrast, the publications in Spanish only (or almost exclusively) are frequented by just $33.3 \%$ doctors (4 out of 12 ).

In conclusion to research question number one, we found general agreement on proposed items related to Language for literacy and Literacy for professional development themes. Professors displayed major agreement with the items from the thematic line Language for literacy, in particular for the item 1(Literacy development in ESL involves a focus on all four macroskills) and 2 (Literacy development in L1 facilitates development of literacy in L2 or L3). In as much for the second thematic line, we could observe some discrepancies (indecisiveness and disagreement) in items \#9, \#10, \#11. The item \# 10 reached major disagreement (My level of literacy is the same in Spanish and in the language I teach), which is explained by the fact that Spanish is the mother tongue of the majority and moreover, the teachers who participate in the second phase, some of them report feel comfortable publishing in that language. The statistically relevant differences between doctorate and master degree holders were found in items \#1, \#9, \#11 and \#12, items on the nature of literacy, research and productivity related to literacy, which were endorsed significantly more by teachers with doctorates.

We conclude that beliefs are also shaped by teachers' participation in their respective professional communities, or communities of practice, which are delineated by institutional and national policies. In our research, we have tried to cover one particular aspect of biliteracy, reported by Swales (2000) as overlooked - how and in what context scientific writers develop academic literacies in a first and second language (p.61). It should be mentioned that this research project on literacy is not concluded yet; the ongoing stage complements biliteracy beliefs and practices with an analyses of the artifacts of participant teachers-researchers.

\section{Acknowledgment \& permissions}

The research project forms the part of the macro project of the research network RILE "Red de Investigadores en Lenguas Extranjeras", which was financially supported by the Mexican Ministry of Public Education.

\section{References}

Allen, W. H., \& Paesani, H. (2010). Exploring the feasability of a pedagogy of multilitarcies in introductory foreign language courses. L2 Journal 2(1), 119142.

Anstey, M., \& Bull, G. (2010). Helping teachers to explore multimodal texts. Curriculum \& Leadership Journal, 8(16), 1-5.

Bailey, K.M., Curtis, A., \& Nunan, D. (2001). Pursuing professional development: The self as a source. Boston, MA: Heinle, Cengage Learning. 
Baker, C. (2011). Foundations of Bilingual Education and Bilingualism ( $5^{\text {th }}$ ed.). Bristol, U.K.: Multilingual Matters.

Barton, D. (1994). Literacy: An introduction to the ecology of written language. Oxford. U.K.: Blackwell.

Barton, D. (2007). Literacy: An introduction to the ecology of written language (2nd Ed). Malden, MA: Blackwell.

Barton, D. \& Hamilton, M. (2000). Literacy practices. In D. Barton, M. Hamilton, \& R. Ivanič (Eds.), Situated literacies (pp.7-15). Abingdon, U.K.: Routledge.

Blommaert (2010). The Sociolinguistics of Globalization. Cambridge, U.K.: Cambridge University Press.

Borg, S. (2006). Teacher cognition and language education: Research and practice. London, U.K.: Continuum.

Braine, G. (2002). Academic literacy and the non-native speaker graduate student. Journal of English for Academic Purposes, 1(1), 59-68.

Cadeiro-Kaplan (2004).The literacy curriculum and bilingual education: a critical examination. Nueva York: Peter Lang.

Canagarajah, S. (2013). Translingual practice: Global Englishes and cosmopolitan relations. Abingdon, U. K.: Routledge.

Carlino, P. (2013). Alfabetización académica diez años después. Revista Mexicana de Investigación Educativa 18 (57), 355-381. Recuperado de http://www.redalyc.org/pdf/140/14025774003.pdf

Cassany, D. (2005). Investigaciones y propuestas sobre literacidad actual: Multiliteracidad, Internet y criticidad. Cátedra UNESCO para la lectura y la escritura. Santiago de Chile: Universidad de Chile.

Cassany, D. (2006). Tras las líneas: Sobre la lectura contemporánea. Barcelona: Anagrama.

Cope, B. \& Kalantzis, M. (2013). "Multiliteracies": New Literacies, new learning. In M. R. Hawkins (Ed.), Framing languages and literacies: socially situated views and perspectives (pp. 105-9). NewYork, N.Y.: Routledge.

Crawford Lewis, T., Mora Pablo, I., Lengeling, M., Goodwin, D., \& Buenaventura Rubio, Z. (2014). Resistencia al cambio de identidad en la redacción de una segunda lengua. Lenguas en Contexto 11, 3-39.

Creswell, J. W. (2003). Research design: Qualitative, quantitative, and mixed methods approaches. Thousand Oaks, Ca., USA: Sage.

Crhová, J., Domínguez-Gaona, M.R., Molina-Landeros, R. C. Arias-López R. S., \& Thomas-Ruzic, M. (2014). Las creencias sobre la enseñanza y el desarrollo de literacidad en una segunda lengua de los docentes de la facultad de Idiomas de la UABC. Lenguas en Contexto (Edición Especial), 43-56.

Cross, R. (2011). Monolingual curriculum frameworks, multilingual literacy development: ESL teachers' beliefs. Australian Journal of Language and Literacy 34 (2), 166-180. 
Cummins, J. (2010). Teaching for transfer: Challenging the two solitudes assumption in bilingual education. In J. Cummings y N. H. Hornberger (Eds.), Encyclopedia of Language and Education (2 ${ }^{\text {nd }}$ ed.), Vol. 5: Bilingual Education (pp. 65-75). New York: Springer Science+ Business Media.

Da Silva, H. y Gilbón, D.M. (1995). Procesos de enseñanza y aprendizaje de lenguas extranjeras. In G. Waldegg (Coor.), Procesos de enseñanza y aprendizaje II. V.I. La investigación educativa en los ochenta. Perspectivas para los Noventa (pp. 298-318). México, D.F.: Consejo Mexicano de Investigación Educativa.

Englander, K. (2010). But it would be good in Spanish: An analysis of awkward scholarly writing in English by L2 writers. En S. Santos (Ed.), EFL writing in Mexican universities: research and experience (pp. 55-72). Tepic, Nayarit: Universidad Autónoma de Nayarit.

Ewing, G. (2003). The New Literacy Studies. A point of connection between literacy research and literacy work. Literacies 1(1), 15-21.

Garret, P. (2010). Attidudes to language. New York, N.Y.: Cambridge University Press.

Gee, J. P. (1996). Social linguistics and literacies: Ideology in Discourses (2nd Ed). London, U.K.: Taylor \& Francis.

Gee, J. P. (2000). The New Literacy Studies: from socially situated to the work of the social. In D. Barton, M. Hamilton, \& R. Ivanič (Eds.), Situated literacies (pp.180-196). Abingdon, U.K.: Routledge.

Gee, J. P. (2004). Situated language learning: A critique of traditional schooling. New York, N.Y.: Routledge.

Hamilton, M. (2000). Expanding the new literacy studies, using photographs to explore literacy as social practice. In D. Barton, M. Hamilton \& R. Ivanic (Eds.), Situated literacies: Reading and writing in context (pp.16-34). London, U.K.: Routledge.

Hamilton, M., (2012). Literacy and the politics of representation. Abingdon, U.K.: Routledge.

Heath, S. B. (1983). Ways with words: Language, life, and work in communities and classrooms. Cambridge, U.K.: Cambridge University Press.

Hornberger, N. H. (2003) (Ed.). Contiunua of biliteracy: An ecological framework for educational policy, research, and practice in multilingual settings. Clevedon, U.K.: Multilingual Matters.

Hornberger, N. H. (2013). Biliteracy continua. In In M. R. Hawkins (Ed.), Framing languages and literacies: Socially situated views and perspectives (pp. 149-163). New York, N.Y.: Routledge.

Hyland, K. (2009). Academic Discourse. London, U.K.: Continuum.

Hyland, K. (2016). Academic publishing and the myth of linguistic injustice. Journal of Second Language Writing (March). Retrieved from https://www.researchgate.net/profile/Ken_Hyland/publication/295086366 
Jarvis, S., \& Pavlenko, A. (2008). Crosslinguistic influence in language and cognition. New York, N.Y.: Routledge.

Johns, A. (1997). Text, role, and context: Developing academic literacies. Cambridge: Cambridge University Press.

Johnson, K.E., Golombek, P.R, (2002). Teacher's narrative inquiry as professional development. Cambridge, U.K.: Cambridge University Press.

Langshear, C. (1999). Literacy studies in education: disciplines developments in a post-disciplinary age. In M. Peters (Ed.), After the disciplines (pp 59-75). Westport, Connecticut, EE.UU: Greenwood Press.

Lave, J., \& Wenger, E. (1991). Situated learning: Legitimate peripheral participation. Cambridge, U.K.: Cambridge University Press.

Lea, M. R., \& Street, B. (2006). The "Academic Literacies" model: Theory and applications. Theory Into Practice, 45(4), 368-377. Retrieved from https://www.researchgate.net/publication/47343136 The Academic Literac ies Model Theory and Applications

Lengeling, M. (2007). Falling into the EFL job in Mexico. MEXTSOL Journal, 31(7), 88-96.

Retrieved

from

http://mextesol.net/journal/public/files/67b73a603083ac8083ee0bdc366b

0742.pdf

Lengeling, M. (2013) (Coord.). Entering into the EFL Teaching Profession: Stories of Teacher Socialization in Mexico/Los Inicios en la Profesionalización de Enseñanza de Inglés como Lengua Extranjera: Historias de Socialización de Maestros en México. México: Universidad de Guanajuato- Benemérita Universidad Autónoma de Puebla.

New London Group, (2000). A Pedagogy of multiliteracies. In B. Cope, \& M. Kalantzis (Eds.), Multiliteracies: Literacy learning and the design of social futures (pp.9-36). London, U.K.: Routledge.

Martin-Jones, M. \& Jones, K. (Eds.) (2000). Multilingual literacies: Reading and writing different worlds. Amsterdam: John Benjamins.

Mauranen, A. (2006). Speaking the discipline: Discourse and socialization. In K. Hyland and M. Bondi (Eds.), Academic discourse across disciplines (pp.271-294). Bern: Peter Lang.

Mayring, P. (2000, June). Qualitative content analysis. Forum Qualitative Social Research (On line Journal), 1(2). Retrieved from http://www.qualitativeresearch.net/index.php/fqs/article/view/1089/2385\%3

McWilliams, R., \& Allan, Q. (2014). Embedding academic literacy skills: Towards a best practice model. Journal of University Teaching \& Learning Practice, 11(3/8). Retrieved from http://ro.uow.edu.au/jutlp/vol11/iss3/8

Pajares, M.F. (1992). Teachers' beliefs and educational research: Cleaning up a messy construct. Review of Educational Research, 62(3), 308-332. 
Pennycook, A., \& Otsuji, E. (2015). Metrolingualism: Language in the city. Abingdon, U.K.: Routledge.

Perales-Escudero, M.D. (2010) (Ed.). Literacy in Mexican higher education: Texts and contexts.Puebla, Mexico: Benemérita Universidad Autónoma de Puebla.

Perales-Escudero, M.D., \& Reyes Cruz, M.R. (2014). Enseñanza de estrategias de comprensión inferencial en inglés L2 y su impacto en español L1: Implicaciones teóricas y pedagógicas. Revista Mexicana de Investigación Educativa 19(61), 599-628.

Poplack, S. (2005). Sometimes I'll start a sentence in Spanish y termina en español: Towards a typology of code-switching. In L. Wei (Ed.), Bilingualism Reader (pp. 205-240). London, U.K: Routledge (Taylor and Francis).

Santos, S. (2010) (Ed.). EFL writing in Mexican universities: research and. Tepic, Nayarit: Universidad Autónoma de Nayarit.

Sayer, P. (2007). Exploring options for titulación en licenciaturas in ELT in Mexico:

A case study. MEXTSOL Journal, 31(1), 57-74. Retrieved from http://mextesol.net/journal/public/files/49b08b41f6684a1d394f4ddf1ef26 5ad.pdf

Ramírez-Romero, J. L. (2007). Las investigaciones sobre la enseñanza y el aprendizaje de lenguas extranjeras en México (1st ed.). México, D.F.: Plaza y Valdés S.A. de C.V.

Ramírez-Romero, J. L. (Coord.) (2010). Las investigaciones en la enseñanza de lenguas extranjeras en México: una segunda mirada. México, D. F: UNISONUAEM, UAEH, CENGAGE Learning.

Ramírez-Romero, J. (Ed.) (2013). Una década de búsqueda: las investigaciones sobre la enseñanza y el aprendizaje de lenguas extranjeras en México (2000 - 2011). México, D.F.: Editorial Progreso.

Reyes-Cruz, M.R., \& Hernández-Méndez, E. (2014). Productividad y condiciones para la investigación: El caso de los profesores de lenguas extranjeras. Sinéctica, 42, 1-17. Retrieved from https://sinectica.iteso.mx/index.php/SINECTICA/article/view/72.

Reyes-Cruz, M.R., \& Guttierez-Arce, J.M. (2014). Sentido de autoeficacia en investigación de estudiantes de posgrado. Sinéctica, 45, 1-15. Retrieved from http://www.scielo.org.mx/pdf/sine/n45/n45a11.pdf

Roberts, C. A. (1994). Transferring literacy skills from L1 to L2: From theory to practice. Journal of Educational Issues of Language Minority Students, 13, 209221.

Snyder, I. (2003). Key words: a vocabulary of pedagogy and new media. En E. Bearne, H. Dombey \& Grainger, T. (Eds.), Classroom interaction in literacy. Berkshire, Reino Unido: Mc-Graw-Hill.

Spolsky, B. (1998). Sociolinguistics. [Oxford Introductions to Language Study]. Oxford, U.K.: Oxford University Press. 
Street, B. (1984). Literacy in the theory and practice. Cambridge, U.K.: Cambridge University Press.

Street, B. (2003). What's new in New Literacy Studies? Critical approaches to literacy in theory and practice. Current Issues in Comparative Education, 5(2), 77-91. Teachers College: Columbian University.

Swales, J. M. (1990). Genre Analysis: English in academic and research settings. Cambridge: Cambridge University Press.

Swales, J.M. (2000). Language for specific purposes. Annual Review of Applied Linguistics, 20, 50-76.

Thorne, S.L. (2013). Digital literacies. In M. R. Hawkins (Ed.), Framing languages and literacies: Socially situated views and perspectives (pp. 192-218). New York, N.Y.: Routledge.

Wenger, E. (1998). Communities of practice: Learning, meaning, and identity. Cambridge, U.K: Cambridge Cambridge University Press.

Wertz, R. E. H., Fosmire, M., Purzer, S. Iglesias, A., Van Epps, A., Sapp M. R., \& Dillman, B. G. (2013). Work in progress: Critical thinking and information literacy: Assessing students performance. 120 ${ }^{\text {th }}$ ASEE Annual Conference \& Exposition. Atlanta.

Wilson, A. K. (2015). 50 years of TESOL in Mexico: An interview with Paul Davies. MEXTSOL Journal, 39(4), 1-6. Retrieved from http://www.mextesol.net/journal/index.php?page=journal\&id_article=1220 Zavala, V. (2009). La literacidad o lo que la gente hace con la lectura y escritura. In D. Cassany (Comp.), Para ser letrados voces y miradas sobre la lectura (pp. 2335). Barcelona: Paidós.

\section{Contact}

Jitka Crhová, PhD.,

Laguna de Términos 19600

\#96, Col. El Lago

Tijuana

B.C., Mexico jcrhova@uabc.edu.mx
Dra. María del Rocío Domíguez, Prolongación Jalisco 3465

Col. Madero Sur

Tijuana, B.C.

Mexico

rocio_dominguez@uabc.edu.mx 


\section{Appendices}

\section{Appendix 1: RILE Questionnaire on research problems in the foreign language field - literacy items}

\section{Please rate how much you personally agree or disagree with these statements by circling the corresponding option on the right column. $1=\mathrm{I}$ strongly agree; 2 = I agree; 3 = I cannot decide; 4 = I disagree; 5 = I strongly disagree; 6 = I do not know.}

Note: Literacy is defined as the use of code and written genres, the knowledge of the discourse function and the roles of the reader and the author; the social values associated with the corresponding discourse practices and the thought forms developed in relation to the previous.

\begin{tabular}{|l|l|l|l|l|l|l|}
\hline $\begin{array}{l}\text { 1. Literacy development in ESL involves a focus on all } \\
\text { four macroskills (listening, speaking, reading and } \\
\text { writing). }\end{array}$ & 1 & 2 & 3 & 4 & 5 & 6 \\
\hline $\begin{array}{l}\text { 2. Literacy development in L1 facilitates development } \\
\text { of literacy in L2 or L3. }\end{array}$ & 1 & 2 & 3 & 4 & 5 & 6 \\
\hline $\begin{array}{l}\text { 3. Literacy development implies the use of multimodal } \\
\text { texts (visual communication means). }\end{array}$ & 1 & 2 & 3 & 4 & 5 & 6 \\
\hline $\begin{array}{l}\text { 4. Literacy development involves the effective use of } \\
\text { information and communications technologies (ICT). }\end{array}$ & 1 & 2 & 3 & 4 & 5 & 6 \\
\hline $\begin{array}{l}\text { 5. Literacy development implies to communicate } \\
\text { effectively in collaborative tasks. }\end{array}$ & 1 & 2 & 3 & 4 & 5 & 6 \\
\hline $\begin{array}{l}\text { 6. Literacy development is highly related to the } \\
\text { development of critical thinking. }\end{array}$ & 1 & 2 & 3 & 4 & 5 & 6 \\
\hline $\begin{array}{l}\text { 7. Active participation in the professional community } \\
\text { encourages literacy development. }\end{array}$ & 1 & 2 & 3 & 4 & 5 & 6 \\
\hline $\begin{array}{l}\text { 8. Active participation in research promotes literacy } \\
\text { development. }\end{array}$ & 1 & 2 & 3 & 4 & 5 & 6 \\
\hline $\begin{array}{l}\text { 9. The level of literacy of a professor determines the } \\
\text { level of his/her research. }\end{array}$ & 1 & 2 & 3 & 4 & 5 & 6 \\
\hline $\begin{array}{l}\text { 10. My level of literacy is the same in Spanish and in } \\
\text { the language I teach. }\end{array}$ & 1 & 2 & 3 & 4 & 5 & 6 \\
\hline $\begin{array}{l}\text { 11. My level of literacy is reflected in my academic } \\
\text { production (publications, conferences, etc.). }\end{array}$ & 1 & 2 & 3 & 4 & 5 & 6 \\
\hline $\begin{array}{l}\text { 12. Literacy development is closely related to } \\
\text { professional development. }\end{array}$ & 1 & 2 & 3 & 4 & 5 & 6 \\
\hline
\end{tabular}

